\title{
A Post-Docking Role of Synaptotagmin 1-C2B Domain Bottom Residues R398/399 in Mouse Chromaffin Cells
}

\author{
Q Girish H. Kedar, ${ }^{1}$ Anders S. Munch, ${ }^{3,4}$ Jan R.T. van Weering, ${ }^{2}$ Jörg Malsam, ${ }^{5}$ Andrea Scheutzow, ${ }^{5}$ Heidi de Wit, ${ }^{2}$ \\ Sébastien Houy, ${ }^{3}{ }^{\circledR B}$ Bassam Tawfik, ${ }^{3}$ Thomas H. Söllner, ${ }^{5}$ ○Jakob B. Sørensen, ${ }^{3,4}$ and Matthijs Verhage ${ }^{1,2}$ \\ ${ }^{1}$ Department of Functional Genomics and ${ }^{2}$ Department of Clinical Genetics, Center for Neurogenomics and Cognitive Research, Vrije Universiteit (VU) and \\ VU Medical Center (VUmc), 1081 HV, Amsterdam, The Netherlands, ${ }^{3}$ Neurosecretion Group, Signaling Laboratory, Department of Neuroscience and \\ Pharmacology and ${ }^{4} \mathrm{C}$ enter for Biomembranes in Nanomedicine, University of Copenhagen, DK-2200 Copenhagen N, Denmark, and ${ }^{5}$ Heidelberg University \\ Biochemistry Center, D-69120 Heidelberg, Germany
}

Synaptotagmin-1 (Syt1) is the principal $\mathrm{Ca}^{2+}$ sensor for vesicle fusion and is also essential for vesicle docking in chromaffin cells. Docking depends on interactions of the Syt1-C2B domain with the t-SNARE SNAP25/Syntaxin1 complex and/or plasma membrane phospholipids. Here, we investigated the role of the positively charged "bottom" region of the C2B domain, proposed to help crosslink membranes, in vesicle docking and secretion in mouse chromaffin cells and in cell-free assays. We expressed a double mutation shown previously to interfere with lipid mixing between proteoliposomes and with synaptic transmission, Syt1-R398/399Q (RQ), in syt1 null mutant cells. Ultrastructural morphometry revealed that Syt1-RQ fully restored the docking defect observed previously in syt1 null mutant cells, similar to wild type Syt1 (Syt1-wt). Small unilamellar lipid vesicles (SUVs) that contained the v-SNARE Synaptobrevin2 and Syt1-R398/399Q also docked to t-SNARE-containing giant vesicles (GUVs), similar to Syt1-wt. However, unlike Syt1-wt, Syt1-RQinduced docking was strictly $\mathrm{PI}(4,5) \mathrm{P}_{2}$-dependent. Unlike docking, neither synchronized secretion in chromaffin cells nor $\mathrm{Ca}^{2+}$ triggered SUV-GUV fusion was restored by the Syt1 mutants. Finally, overexpressing the RQ-mutant in wild type cells produced no effect on either docking or secretion. We conclude that the positively charged bottom region in the C2B domain - and, by inference, Syt1mediated membrane crosslinking - is required for triggering fusion, but not for docking. Secretory vesicles dock by multiple, $\mathrm{PI}(4,5) \mathrm{P}_{2^{-}}$ dependent and $\mathrm{PI}(4,5) \mathrm{P}_{2}$-independent mechanisms. The R398/399 mutations selectively disrupt the latter and hereby help to discriminate protein regions involved in different aspects of Syt1 function in docking and fusion.

Key words: mouse chromaffin cells; patch-clamp technique; synaptotagmin-1; ultrastructural analysis

Significance Statement

This study provides new insights in how the two opposite sides of the C2B domain of Synaptotagmin-1 participate in secretory vesicle fusion, and in more upstream steps, especially vesicle docking. We show that the "bottom" surface of the C2B domain is required for triggering fusion, but not for docking. Synaptotagmin-1 promotes docking by multiple, $\mathrm{PI}(4,5) \mathrm{P}_{2}$-dependent and $\mathrm{PI}(4,5) \mathrm{P}_{2}$-independent mechanisms. Mutations in the C2B bottom surface (R398/399) selectively disrupt the latter. These mutations help to discriminate protein regions involved in different aspects of Synaptotagmin-1 function in docking and fusion.

\section{Introduction}

Fusion of secretory vesicles with the plasma membrane depends on the assembly of v-SNARE (Synaptobrevin2) and t-SNAREs

Received May 18, 2015; revised Aug. 27, 2015; accepted Sept. 3, 2015.

Author contributions: G.H.K., J.R.T.v.W., H.d.W., T.H.S., J.B.S., and M.V. designed research; G.H.K., A.S.M., J.M., A.S., S.H., and B.T. performed research; G.H.K., A.S.M., J.R.T.v.W., J.M., A.S., S.H., B.T., T.H.S., and J.B.S. analyzed data; G.H.K., T.H.S., and J.B.S. wrote the paper.

This work was supported by grants from the Erasmus Mundus Joint Doctorate Program (SGA 2011-1632-001EMJD; G.H.K.), the Fonds Economische Structuurversterking NeuroBasic PharmaPhenomics grant (Agentschap NL FES0908; M.V.), the European Research Council (ERC-ADG-322966-DCVfusion; M.V.), the Netherlands Organization for Scientific Research (MEERVOUD-836.10.002; H.d.W.), the European Neuroscience Campus Network (Cycle 2-project 7; H.d.W., M.V.), the Lundbeck Center for Biomembranes in Nanomedicine (J.B.S.), and the Novo Nordisk
(SNAP25/Syntaxin1) into a SNARE-complex (for review, see Jahn and Scheller, 2006; Südhof and Rothman, 2009). Vesicles go through several upstream steps, referred to as docking and priming, to gain fusion competence (Verhage and Sørensen, 2008). The vesicular protein Synaptotagmin-1 (Syt1) is the principal $\mathrm{Ca}^{2+}$ sensor for fusion in many CNS neurons and in neuroendocrine cells (Geppert et al., 1994; Fernández-Chacón et al., 2001;

Foundation (J.B.S.). We thank Joke Wortel, Christiaan van der Meer, Joost Hoetjes, Frank den Oudsten, and Erik Ceelen for breeding and genotyping mice, Robbert Zalm for cloning and producing viral vectors, and Anne Marie Nordvig Petersen for excellent technical assistance. We thank Prof. Dr. Christian Rosenmund (Charite Medical University, Berlin) for providing the Syt1-RQ mutant construct and Dr. Sophie van der Sluis for advice on the statistical analysis of nested data. 
A

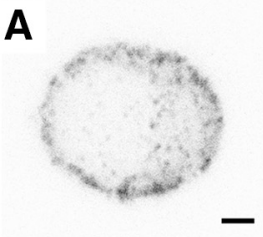

wild type
B

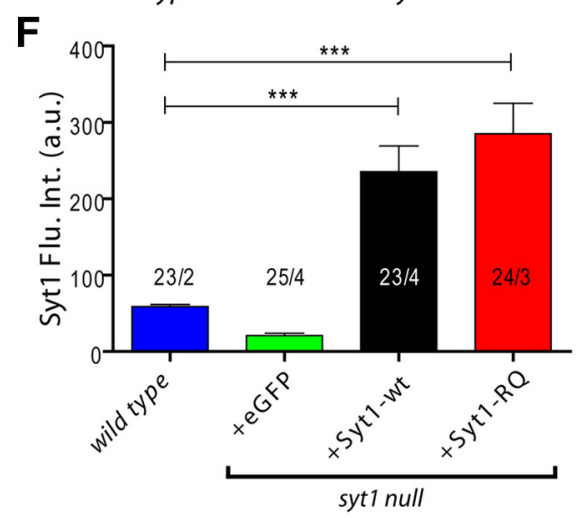

C
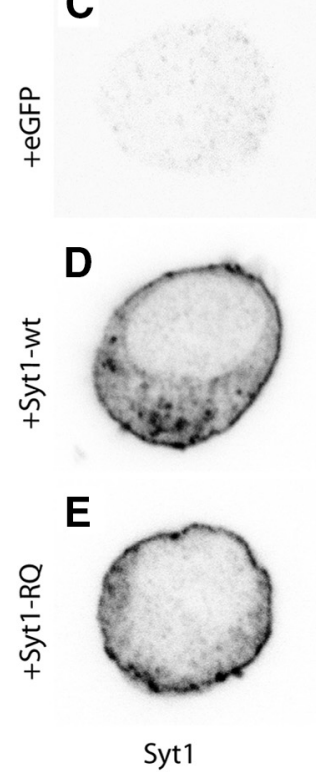
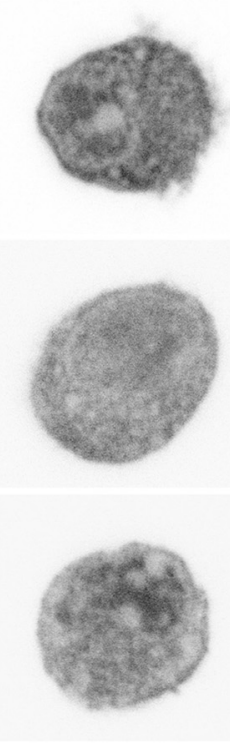

eGFP
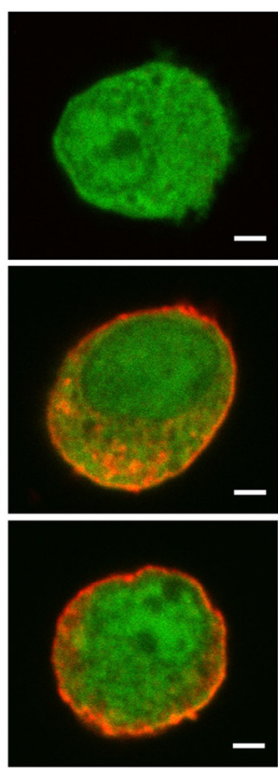

Merge

Figure 1. SFV transfection leads to overexpression of Syt1-wt and the Syt1-RQ mutant. $A, B$, Syt1 is located near the plasma membrane in wild type chromaffin cells $(\boldsymbol{A})$ and is absent in syt1 null cells $(\boldsymbol{B})$. $\boldsymbol{C}-\boldsymbol{E}$, eGFP overexpression does not change Syt1 expression in the syt1 null cell $(\boldsymbol{C})$, whereas Syt1-wt $(\boldsymbol{D})$ and Syt1-RQ mutant $(\boldsymbol{E})$ transfection result in $4-5 \times$ overexpression $(0 \mathrm{E})$. Scale bars: $2 \mu \mathrm{m}$. $\boldsymbol{F}$, Quantification of Syt1 levels by multilevel analysis. Between 3 and 14 cells were collected from two to four embryos per condition, and overall cell numbers and embryo numbers are annotated. ${ }^{* * *} p \leq 0.001$. Error bars indicate SEM. Flu. Int., Fluorescence intensity.

Voets et al., 2001) and is also part of the docking complex for secretory granules (de Wit et al., 2009). Interactions between Syt1 and the t-SNAREs mediate docking in neuroendocrine cells (de Wit et al., 2009; Mohrmann et al., 2013), consistent with previous findings in invertebrate neurons (Jorgensen et al., 1995; Reist et al., 1998; Loewen et al., 2006). Previously, Syt1 deficiency was shown to also impair synaptic vesicle accumulation near the active zone in mammalian CNS neurons (Imig et al., 2014). Syt1 contains a transmembrane domain and a tandem of $\mathrm{C} 2$ domains, which bind $\mathrm{Ca}^{2+}$ ions and contain many positively and negatively charged amino acids for potential electrostatic interactions with t-SNAREs, $\mathrm{PI}(4,5) \mathrm{P}_{2}$, and other interactors (Fernandez et al., 2001; Pang et al., 2006; Chapman, 2008; Pang and Südhof, 2010; Jahn and Fasshauer, 2012; Park et al., 2012).

The electrostatic interactions supporting the role of Syt 1 in docking are probably located in a polybasic patch, centered around K326/327 on the Syt1-C2B domain, that interacts with t-SNAREs (Rickman et al., 2004). The same polybasic stretch also binds PI(4,5) $\mathrm{P}_{2}$ (Fernandez et al., 2001; Rizo et al., 2006; Chapman, 2008; Jahn and Fasshauer, 2012; Park et al., 2012), and this interaction occurs at sites where Syntaxin 1 and $\mathrm{PI}(4,5) \mathrm{P}_{2}$ form clusters (Honigmann et al., 2013). Syt1 might also mediate docking by simultaneous binding of two opposing membranes. This property of Syt 1 was shown in vitro and depends on the calciumbinding region on the "top" and on two arginines at the "bottom" of the C2B domain (Araç et al., 2006; Xue et al., 2008). Indeed, mutations in this bottom region (R398Q, R399Q, called the RQ mutant) abolished neurotransmitter release in neurons (Xue et al., 2008), and the single mutation (R398A) impaired $\mathrm{Ca}^{2+}$ -

G.H.K. and A.S.M. contributed equally to this work.

The authors declare no conflict of interest.

Correspondence should be addressed to Matthijs Verhage, Department of Functional Genomics and Clinical Genetics, Center for Neurogenomics and Cognitive Research, Neuroscience Campus Amsterdam, VU and VUmc, 1081 HV, Amsterdam, The Netherlands. E-mail: matthiis@cncr.vu.nl.

DOI:10.1523/JNEUROSCI.1911-15.2015

Copyright $\odot 2015$ the authors $\quad 0270-6474 / 15 / 3514173-11 \$ 15.00 / 0$ dependent Syt 1 function in a lipid mixing assay (Gaffaney et al., 2008). However, it is unknown whether these mutations also affect vesicle docking and whether potential docking defects contribute to the observed effects on release. A homologous mutation in Syt2 (R399Q, R400Q) was proposed to affect positional priming (Young and Neher, 2009). Again, it is unknown whether this overexpression of Syt2-RQ affects vesicle distribution.

In this study we aimed to resolve the role of the Syt1-C2B bottom domain in docking and secretion by expressing wild type Syt1 and the RQ mutant in syt1 null chromaffin cells and by comparing both Syt 1 variants in an in vitro liposome docking and fusion assay (Malsam et al., 2012). We found that the bottom residues are critical for fast Syt1-dependent fusion, but dispensable for docking. However, docking becomes critically dependent on $\mathrm{PI}(4,5) \mathrm{P}_{2}$. Hence, the RQ mutant helps to segregate different aspects of Syt 1 function in docking and fusion.

\section{Materials and Methods}

Cell culture and transfection of chromaffin cells

Mouse chromaffin cells were obtain by isolating adrenal glands of wild type or synaptotagmin-1 null littermates [embryonic day 18 (E18) pups of either sex] and cultured as described previously (Sørensen et al., 2003; de Wit et al., 2009). Cells were infected on day in vitro 3 for 8-12 h with Semliki Forest virus (SFV; Ehrengruber and Lundstrom, 2007) containing full-length synaptotagmin-1-IRES-eGFP or syt1 (R398,399Q)-IRES-eGFP (a gift from Dr. C. Rosenmund, Charite Medical University, Berlin, Germany; Xue et al., 2008). In ultramorphology analysis experiments, SFV expressing IRES-eGFP was used as a control.

\section{Confocal microscopy}

Cells were fixed using 4\% paraformaldehyde (Merck) in PBS, pH 7.4, for $1 \mathrm{~h}$, permeabilized with $1 \%$ Triton X-100 in PBS for $5 \mathrm{~min}$, and blocked for 30 min with solution containing PBS, $2 \%$ NGS, and $1 \%$ Triton X-100. Cells were then incubated with primary antibody [polyclonal rabbit antisynaptotagmin 1, 1:2000 (W855; a gift from T. C. Südhof, Stanford, CA) or polyclonal rabbit anti-chromoganinB, 1:500 (Synaptic System)] for $1 \mathrm{~h}$, washed, and then incubated with secondary antibody (goat-anti- 
rabbit Alexa Fluor 546, 1:1000; Sigma) for $1 \mathrm{~h}$. Cell fixation and staining procedures were performed at room temperature. Coverslips were mounted on glass slides using Mowiol 4-88 (Aldrich). A confocal laser scanning microscope (LSM 500 meta; Carl Zeiss Microimaging) was used to image stained cells. Infected cells were identified based on eGFP fluorescence. Images were taken using a $63 \times / 1.4 \mathrm{nu}-$ merical aperture oil-immersion objective lens. Fluorescence intensity was calculated using Fiji (Schindelin et al., 2012).

\section{Electrophysiological recordings}

Transfected cells were identified by green fluorescent response to $475 \mathrm{~nm}$ illumination by a monochromator (Polychrome IV; TILL Photonics). Amperometry measurements were performed with 5 - $\mu \mathrm{m}$-diameter polyethylene insulated carbon fibers (Thornel P-650/42; Cytec; Bruns, 2004). The tip of the fiber was gently pressed against the cell while a constant voltage of $700 \mathrm{mV}$ was applied. Currents were amplified by an EPC-7 amplifier (HEKA Elektronik), filtered at $2.9 \mathrm{kHz}$, and sampled at 11.5 $\mathrm{kHz}$. Cell membrane capacitance was measured via whole-cell patch-clamp technique as described by Lindau and Neher (1988). Pulse software (version 8.53) and an EPC-9 amplifier (HEKA Elektronik) were used in "sine $+\mathrm{dc}$ " mode to record and inject currents. Currents were filtered at $3 \mathrm{kHz}$ and sampled at $11.5 \mathrm{kHz}$. Secretion was stimulated by UV photolysis of the $\mathrm{Ca}^{2+}$ cage nitrophenyl-EGTA by using UV light from a UV flash lamp (JML-C2; Rapp Optoelectronics) or by applying depolarizing pulses both controlled by the Pulse software and triggered by the EPC- 9 amplifier.

Chromaffin cells were visualized using a Zeiss Axiovert 10 with a $40 \times$ Fluar objective (Carl Zeiss). $\mathrm{Ca}^{2+}$ measurements were conducted by exciting Fura dyes at 350 and 380 $\mathrm{nm}$. Emitted light was detected by a photo diode (Till Photonics) in an area around the cell defined by a View Finder (Till Photonics). The output of the photo diode was connected to an auxilliary input channel on the EPC-9 amplifier. The signal was filtered at 3 $\mathrm{kHz}$ and sampled at $11.5 \mathrm{kHz}$. The $\mathrm{Ca}^{2+}$ concentration was measured with a mixture of high- and low-affinity Fura dyes as described previously (Voets, 2000). The free $\mathrm{Ca}^{2+}$ concentrations were calculated using a customwritten macro for IGOR Pro (Wavemetrics), assuming a $K_{\mathrm{D}}$ of $0.222 \mu \mathrm{M}$ for BAPTA and of $80 \mu \mathrm{M}$ for DPTA while taking into account the additional buffering of $\mathrm{Ca}^{2+}$ by the dyes, nitrophenyl-EGTA, and ATP. The patch pipette solution contained the following (in mM): 100 Cs-glutamate, $8 \mathrm{NaCl}, 4 \mathrm{CaCl}_{2}$, 32 HEPES, 2 Mg-ATP, 0.3 NaGTP, 5 nitrophenyl-EGTA, 1 ascorbic acid, 0.4 fura- $4 \mathrm{~F}$ (Invitrogen), and 0.4 furaptra (Invitrogen), adjusted to $\mathrm{pH} 7.2$ with $\mathrm{CsOH}$.

Electron microscopy of cultured chromaffin cells

Cells were fixed using conventional aldehyde fixation protocol with $2.5 \%$ glutaraldehyde in $0.1 \mathrm{M}$ cacodylate buffer, $\mathrm{pH} 7.4$, for $1 \mathrm{~h}$ and subsequently washed with $0.1 \mathrm{~m}$ cacodylate buffer, $\mathrm{pH}$ 7.4. Postfixation was
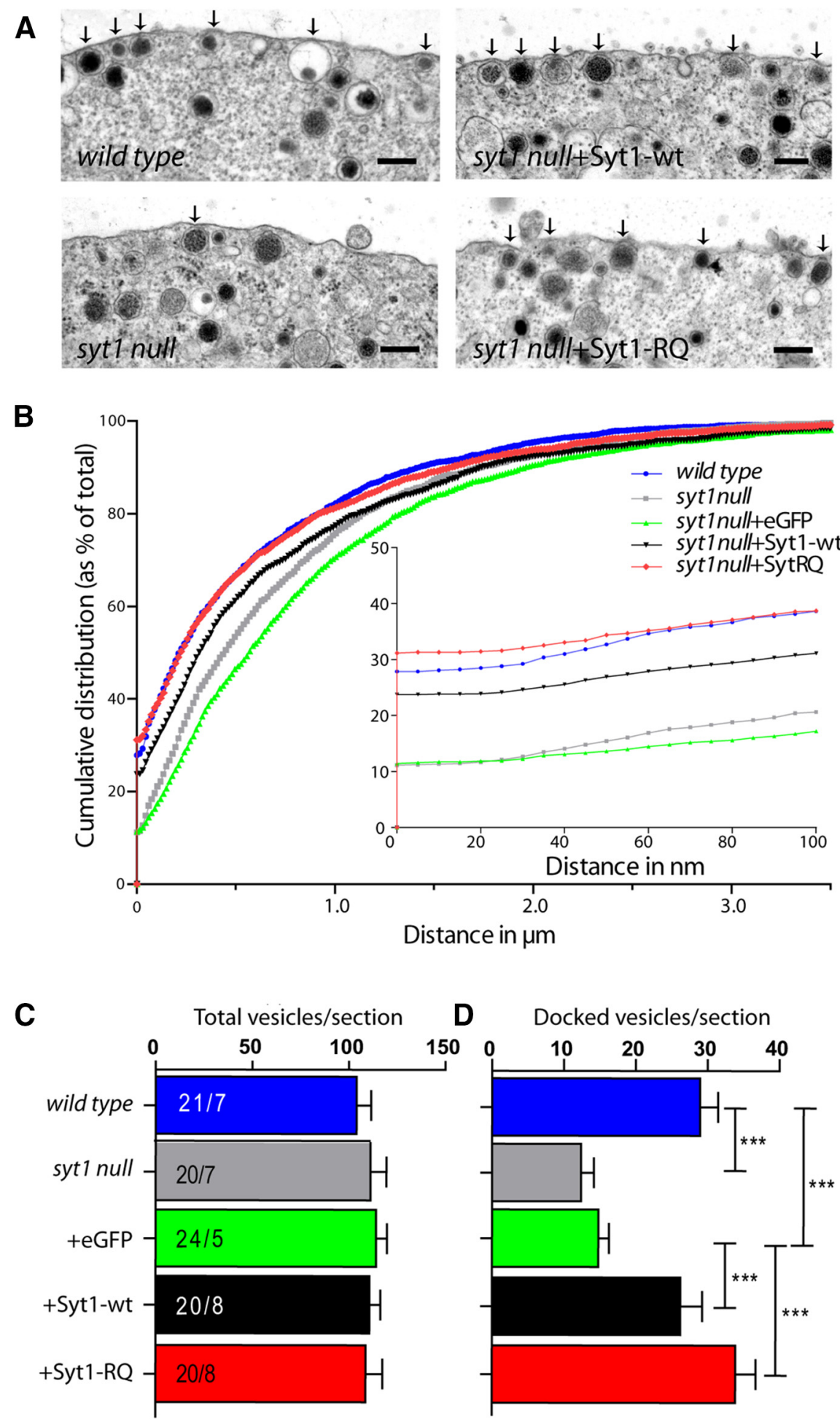

Figure 2. Syt1-RQ mutant rescues docking in syt1 null cells. $A$, Ultrastructural images of different noninfected and infected conditions on the syt1 null cell background. Arrows mark docked vesicles. Scale bars: $200 \mathrm{~nm}$. $\boldsymbol{B}$, Normalized cumulative distribution of vesicles as a function of the distance from the plasma membrane. Inset, Distance in the range of $0-100 \mathrm{~nm}$ from membrane. $\boldsymbol{C}, \boldsymbol{D}$, Number of total $(\boldsymbol{C})$ and docked $(\boldsymbol{D})$ vesicles per section showing no difference in docking for Syt1-RQ mutant. ${ }^{* * *} p \leq 0.001$ by multilevel analysis (between 1- 8 cells were collected from 5- 8 embryos per condition; overall cell numbers and embryo numbers are annotated in (). Error bars indicate SEM.

done for $1.5 \mathrm{~h}$ using $1 \%$ osmium tetroxide and $1 \%$ ruthenium tetroxide mixture in $0.1 \mathrm{M}$ cacodylate buffer. Due to cell detachment in highpressure freezing/freeze substitution (HPF/FS) protocols, HPF/FS could not be applied. Since a side-by-side comparison between aldehyde fixation and HPF/FS on large dense core vesicles docking revealed no differ- 
A

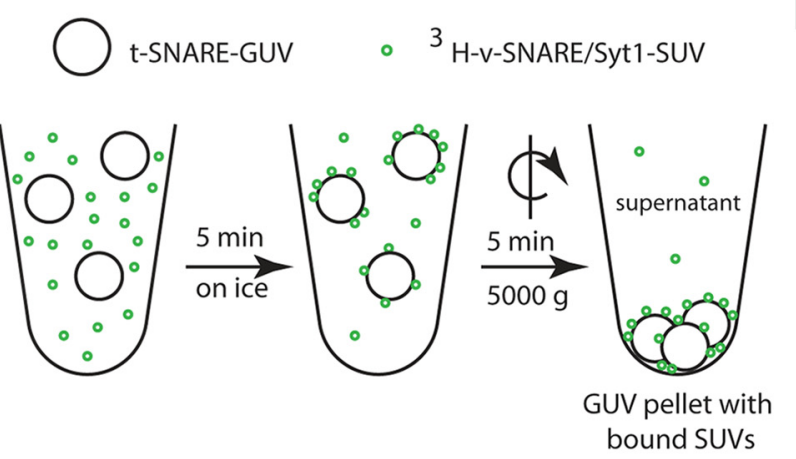

C

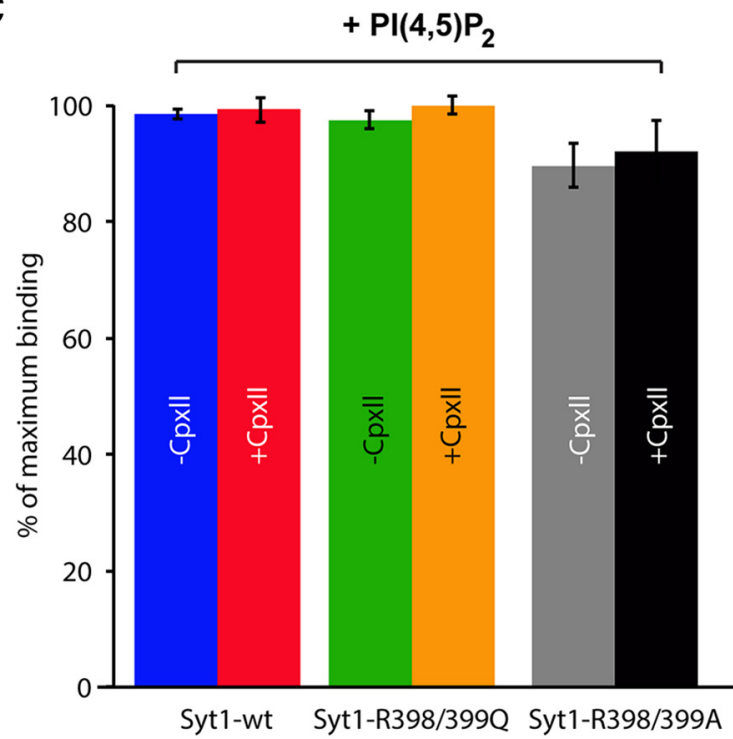

B

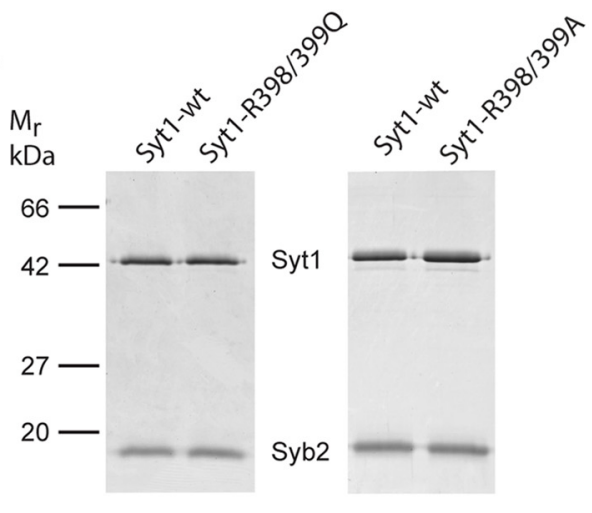

$-\mathrm{PI}(4,5) \mathrm{P}_{2}$
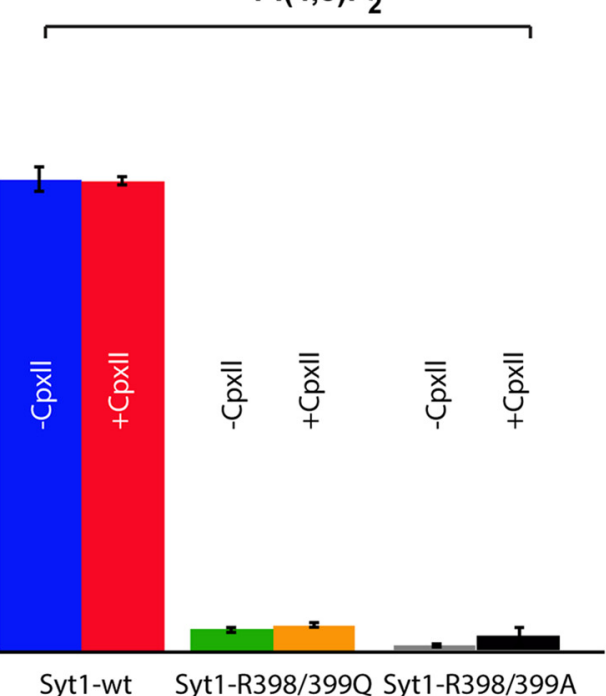

Figure 3. Syt1-R398/399Q- and Syt1-R398/399A-dependent vesicle docking requires the presence of $\mathrm{PI}(4,5) \mathrm{P}_{2}$ in a reconstituted SUV-GUV docking assay. $A$, Scheme of vesicle docking assay. t-SNARE-GUVs (28 nmol lipid, $28 \mathrm{pmol}$ Syntaxin1/SNAP-25) lacking or containing 2\% PI(4,5)P ${ }_{2}$ were mixed with ${ }^{3} \mathrm{H}$-labeled v-SNARE/Syt1-SUVs (5 nmol lipid, $16.6 \mathrm{pmol}$ Synaptobrevin2, $6.2 \mathrm{pmol}$ Syt1), containing either Syt1-wt or Syt1-R398/3990 or Syt1-RA in the presence and absence of $6 \mu \mathrm{m}$ Complexin II (Cpxll). Samples were incubated in a final volume of $100 \mu \mathrm{l}$ for 5 min on ice to allow docking, followed by centrifugation at $5000 \times g$ for 5 min to reisolate GUVs. B, Reconstituted SUVs, containing Synaptobrevin2 (Syb2) and either Syt1-wt or Syt1-R398/3990 or Syt1-RA, were analyzed by SDS-PAGE and Coomassie blue staining. $C,{ }^{3} \mathrm{H}$-labeled SUVs bound to GUVs in the pellet were quantified and normalized to maximum binding. Error bars indicate SEM ( $n=3$ ).

ences in conclusions (de Wit et al., 2009), we relied on chemical fixation in this study. Dehydration using a series of ethanol concentrations (30$100 \%$ ) was performed followed by embedding in Epon and polymerization for at least $15 \mathrm{~h}$ at $65^{\circ} \mathrm{C}$. The coverslip was removed from Epon resin by alternatively dipping it into liquid nitrogen and hot water. Flat Epon surface region $(2 \times 3 \mathrm{~mm})$ with a high cell density monolayer was selected, cut, and mounted on prepolymerized Epon blocks for thin sectioning. Ultrathin sections $(\sim 90 \mathrm{~nm})$ were collected on single-slot, formvar-coated copper grids and stained with uranyl acetate and lead citrate. A Jeol 1010 transmission electron microscope was used for highresolution imaging. Vesicle membrane attached to the plasma membrane was considered docked vesicles. An infected cell was identified based on presence of SFV (droplet shape with dense core) on the plasma membrane. Distance measurements were performed using $10,000 \times$ or $30,000 \times$ magnification images on iTEM software (Olympus).

\section{Reconstituted SUV-GUV docking and fusion assays}

Proteins were expressed, purified, and reconstituted into liposomes as described previously (Weber et al., 1998; Malsam et al., 2012). The following modifications were made: The C-terminal $\mathrm{His}_{6}$-tag of full length mouse Synaptobrevin2 was replaced by an N-terminal GST-tag, which was removed by thrombin cleavage before reconstitution of Synaptobrevin2 into v-SNARE/Syt1 liposomes. Therefore, a cDNA encoding mouse Synaptobrevin2 (pTW2) was amplified by PCR and subcloned into pGEX4T3 using BamHI and XhoI sites resulting in pSK28. To in- troduce the R398/399Q (RQ) and R398/399A (Syt1-RA) double mutations into Syt1, the template plasmid pLM6, encoding Syt1 (Mahal et al., 2002), was modified using the QuickChange DNA mutagenesis method (Qiagen). The resulting constructs pJM80 and pJM45 encode $\mathrm{His}_{6}$-rat Syt1 R398/399Q and $\mathrm{His}_{6}$-rat Syt1 R398/399A, respectively.

For the preparation of giant unilamellar t-SNARE vesicles (GUVs), indium tin oxid (ITO)-coated glass slides were replaced by Pt-coated glass slides (GeSIM). In addition, in the GUV preparation buffer $1 \mathrm{mM}$ HEPES-KOH, pH 7.4, was replaced by $0.5 \mathrm{~mm}$ EPPS-KOH [3-[4-(2hydroxyethyl)-1-piperazinyl]propanesulfonic acid hydrate], $\mathrm{pH}$ 8.0. In the lipid mix used for the reconstitution of the v-SNARE/Syt1 small unilamellar lipid vesicles (SUVs), the fluorophores rhodamine-DPPE [ $N$-(lissamine rhodamine B sulfonyl)1,2-dipalmitoyl phosphatidylethanolamine] and NBD-DPPE [ $N$-(7-nitro-2,1,3-benzoxadiaziole-4-yl)1,2-dipalmitoyl phosphatidylethanolamine] were replaced by $0.5 \mathrm{~mol} \%$ each of Atto488-DPPE and Atto550-DPPE [Atto-dye labeled phospholipids 1,2-dipalmitol-sn-glycero-3-phosphoethanolamine] from Atto-Tec.

SUV-GUV docking and fusion reactions and data analysis were performed as described previously (Malsam et al., 2012). Briefly, incubations occurred in an iso-osmolar buffer containing 25 mM HEPES-KOH, pH 7.4, $135 \mathrm{~mm} \mathrm{KCl}, 0.5 \mathrm{~mm} \mathrm{MgCl}, 1 \mathrm{~mm}$ dithiothreithol, and $100 \mu \mathrm{M}$ EGTA. Calcium was added to a free concentration of $100 \mu \mathrm{M}$ using the Maxchelator software (http://maxchelator.stanford.edu). 
A
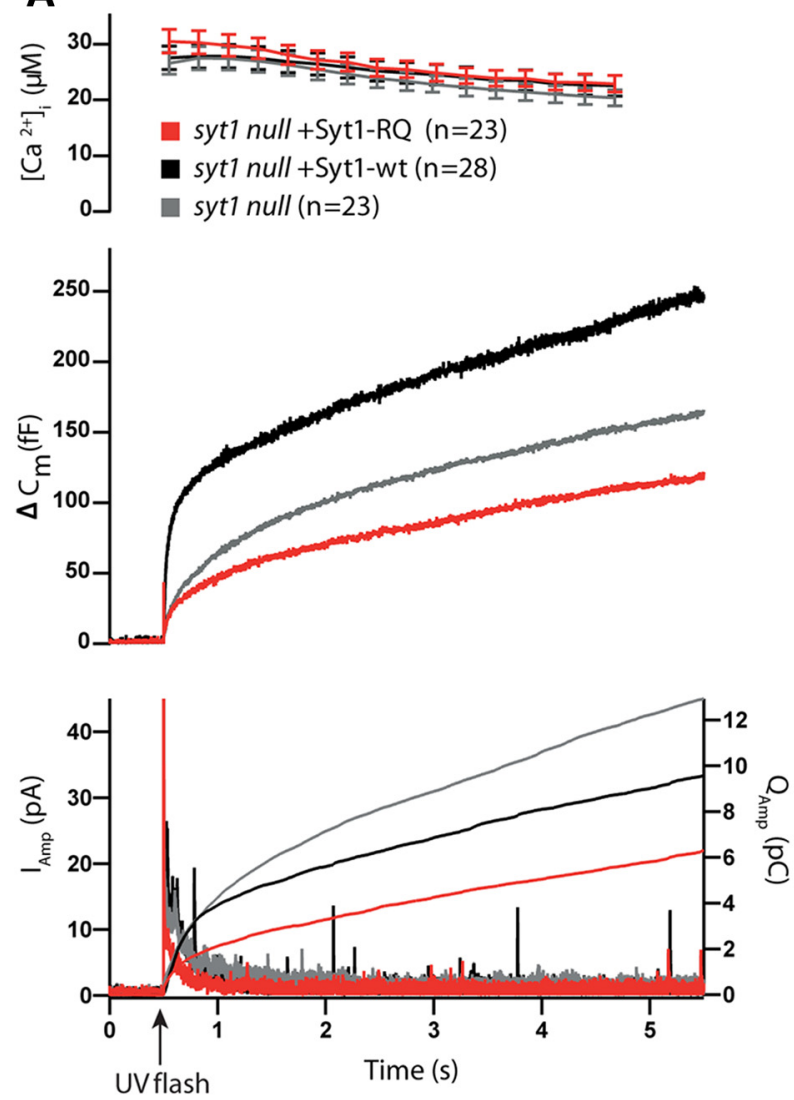

B

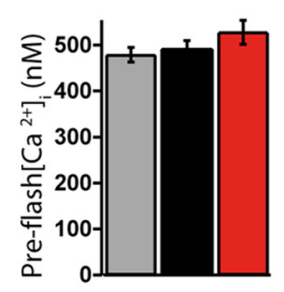

E

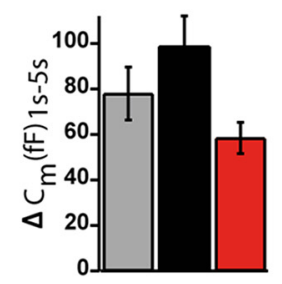

H

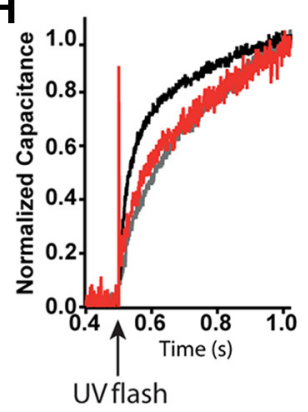

C

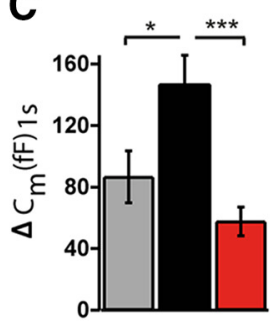

F

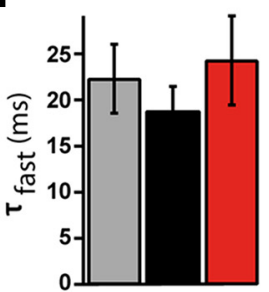

I

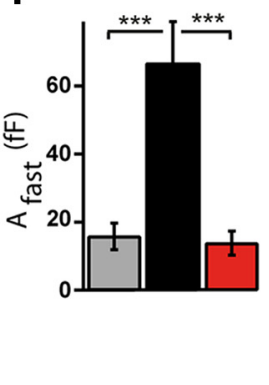

D

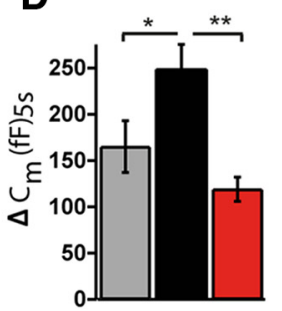

G

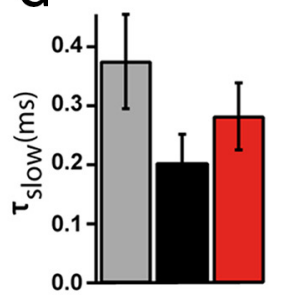

J

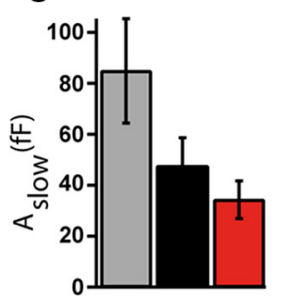

Figure 4. Syt1-RQ mutant impaired secretion in syt1 null cells. A, Mean membrane capacitance and $\mathrm{Ca}^{2+}$ measurements of syt1 null (gray) with Syt1-wt overexpression (black) and Syt1-RQ mutant (red). $\boldsymbol{B}$, Quantification of preflash $\left[\mathrm{Ca}^{2+}\right]$. C, Burst size was higher in Syt1-wt overexpression than Syt1-RQ overexpression and syt 1 null $\left(\Delta C_{\mathrm{m}}\right.$ at $1 \mathrm{~s}$; Kruskal-Wallis test, $p<0.001$; result of pairwise post-tests, syt1 null vs Syt1-wt overexpression, $p=0.016$; Syt1-wt overexpression vs Syt1-RQ, $p<0.001)$. D. The same was true of total release size $\left(\Delta C_{\mathrm{m}}\right.$ at $5.5 \mathrm{~s}$, Kruskal-Wallis test, $p=0.004$; result of pairwise post-tests, syt1 null vs Syt1-wt overexpression, $p=0.035$; Syt1-wt overexpression vs Syt1-RQ, $p=0.005$ ). $\boldsymbol{E}$, For sustained release, the difference was almost, but not quite, significant $\left(\Delta C_{\mathrm{m}}\right.$ at $5.5-1 \mathrm{~s}$; Kruskal-Wallis test, $\left.p=0.051\right) . \boldsymbol{F}, \mathbf{G}, \mathbf{I}, \boldsymbol{J}$, Fitting individual capacitance traces with a sum of exponentials allowed separating the amplitude and time constant of fast burst secretion from the amplitude and time constant of slow burst secretion. Only the amplitude of the fast burst $\left(A_{\text {fast }}\right.$ ) was significantly different between groups (Kruskal-Wallis test, $p<$ 0.001; result of pairwise post-tests, syt1 null vs Syt1-wt overexpression, $p<0.001$; Syt1-wt overexpression vs Syt1-RQ, $p<0.001$ ). $\boldsymbol{H}$, Scaled version of the mean capacitance traces in $\boldsymbol{A}$ clearly show the fast component in the Syt1-wt overexpression, which is missing from syt 1 null and Syt1-RQ overexpression. Error bars indicate SEM.

\section{Statistics}

Physiology data. When three groups were compared (typically WT overexpression, RQ mutant overexpression, and a control group), a nonparametric Kruskal-Wallis test for independent samples was used to compare the distributions. If the test was significant, a post-test with significance levels corrected for multiple comparisons was used for pairwise testing (IBM SPSS Statistics, version 22). A significance level of 0.05 was assumed throughout.

Ultrastructural morphometry. The data obtained from individual cells was nested within individual embryos (more than one observation drawn from one independent sample, an embryo). To accommodate potential dependency, we tested the effects by multilevel analysis using SPSS (IBM) software (Aarts et al., 2014). The number obtained per embryo for each data set is noted in each figure legend; overall cell numbers and embryo numbers are annotated in the figures.

\section{Results}

Syt1 null chromaffin cells (E18) show impaired docking and a $\mathrm{Ca}^{2+}$-dependent fast burst release component (Voets et al., 2001; Nagy et al., 2006; Schonn et al., 2008; de Wit et al., 2009). We used this model to analyze the role of the Syt1-C2B bottom domain in docking and secretion by introducing exogenous Syt1-wt-IRESeGFP or Syt1-RQ-IRES-eGFP. We assessed the level and localization of the overexpressed Syt1 by confocal microscopy. Endogenous Syt1 labeling shows a punctate pattern that is concentrated in the vicinity of the plasma membrane (Fig. 1A). This labeling is absent in syt1 null cells, indicating that this labeling is specific for Syt1 (Fig. 1 B, C). Syt1 null cells expressing the Syt1-wt and Syt1-RQ constructs showed a distribution of Syt1 close to plasma membrane (Fig. 1D,E), comparable to the endogenous Syt1 pattern. This indicates that the RQ mutation had no effect on the subcellular distribution of Syt1. Both constructs yielded a significant increase in Syt1 levels of a factor of four over wild type levels (multilevel test against wild type; syt 1 null + eGFP, $p=0.389$; syt 1 null + Syt1-wt and syt1 null + Syt1-RQ, $p \leq 0.001$; Fig. $1 F)$.

\section{Syt1-C2B bottom region is dispensable for secretory vesicle docking}

We first assessed the secretory vesicle distribution in syt 1 null cells expressing Syt1-wt or the Syt1-RQ mutant by electron microscopy. In line with previously reported observations in syt1 null cells (de Wit et al., 2009), we found a $>50 \%$ reduction in docked vesicles in syt1 null cells compared to wild type ( $p \leq 0.001$; Fig. $2 A-D)$. Moreover, Syt1-wt restored docking in syt1 null cells to the wild type level, without affecting the total number of vesicles: wild type, $29 \pm 2.5$ ( $p \leq 0.001$ against syt 1 null + eGFP $) ;$ syt 1 null + Syt1-wt, $26.3 \pm 2.9(p \leq 0.001$ against syt1 null + eGFP $) ;$ syt 1 null, $12.4 \pm 1.8(p=0.656$ against syt 1 null + eGFP $) ;$ syt 1 null + eGFP, $14.8 \pm 1.4$ docked vesicles/section. Total number of vesicles ranged from $104 \pm 7$ to $114 \pm 5$ vesicles/section in all con- 


\section{Syt1 R398/399Q}

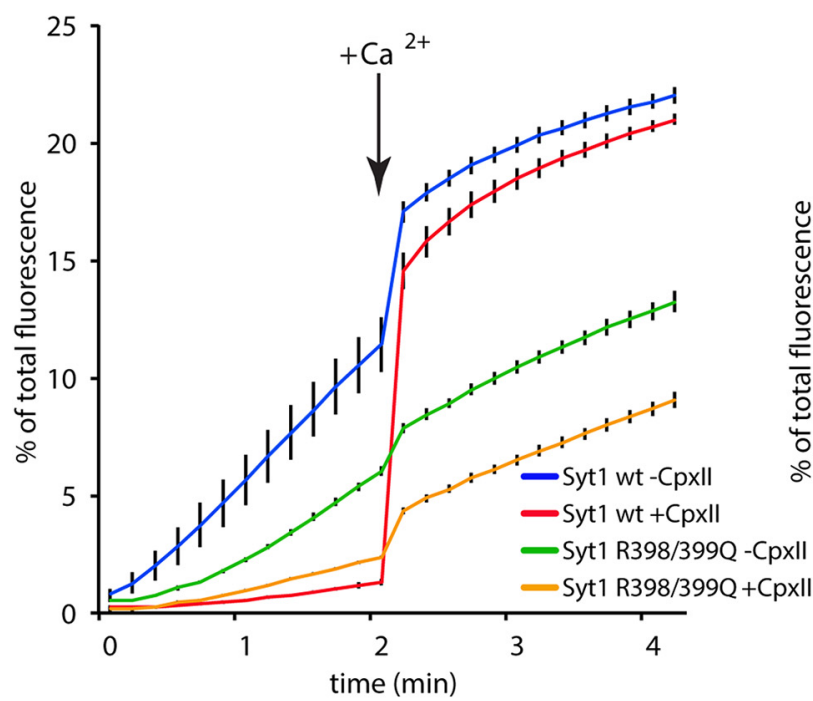

Syt1 R398/399A

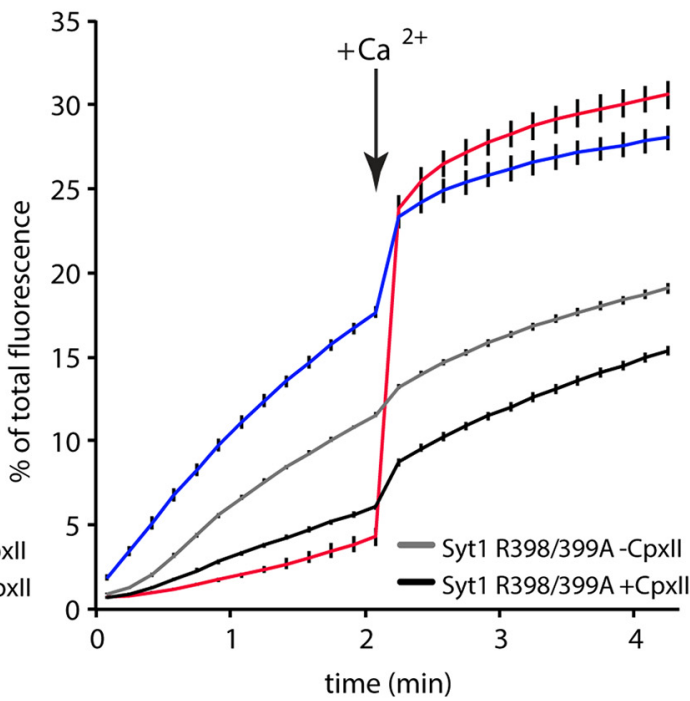

Figure 5. Syt1-RQ and Syt1-RA mutants fail to promote $\mathrm{Ca}^{2+}$-triggered lipid mixing in a reconstituted SUV-GUV fusion assay. t-SNARE-GUVs (14 nmol lipid, $14 \mathrm{pmol}$ Syntaxin1/SNAP25) were mixed with ${ }^{3} \mathrm{H}$-labeled v-SNARE-SUVs ( $2.5 \mathrm{nmol}$ lipid, $8.3 \mathrm{pmol}$ Synaptobrevin2, $3.1 \mathrm{pmol}$ Syt1) containing either Syt1-wt or Syt1-R398/3990 or Syt1-RA in the presence and absence of $6 \mu \mathrm{M}$ Cpxll in a final volume of $100 \mu \mathrm{l}$. The increase of Atto 488 fluorescence was monitored. After $2 \mathrm{~min}$ at $37^{\circ} \mathrm{C}, \mathrm{Ca}^{2+}$ was added to a final concentration of $100 \mu \mathrm{m}$ and the measurement continued for another 2 min. Values were normalized to the maximum fluorescent signal after detergent lysis. Error bars indicate SEM. $n=3$.

ditions (mean \pm SEM; all not significantly different; Figs. 2C,D). Syt1 null cells expressing the Syt1-RQ mutant showed a similar number of docked vesicles as compared to wild type cells (syt1 null + Syt1-RQ, $33.9 \pm 2.9$ docked vesicles/section, mean \pm SEM, $p=0.154$, multilevel analysis; Fig. $2 A, C)$. Importantly, expressing Syt1-RQ or Syt1-wt on the syt1 null background does not change the total number of vesicles, but shifts the distribution pattern of vesicles to the wild type pattern (Fig. 2B). This indicates that the positive-charged arginines of the Syt1-C2B domain are dispensable for Syt1 function in secretory vesicle docking.

\section{The normal docking functions of Syt1-RQ and RA critically depend on $\mathrm{PI}(4,5) \mathrm{P}_{2}$ in vitro}

Docking in cells might be affected by multiple proteins and proteinprotein as well as protein-lipid interactions. To investigate the role of the Syt1-C2B bottom region in a reduced system, we recapitulated Syt1's role in docking in vitro in a cell-free assay by analyzing docking of SUVs that contain the v-SNARE Synaptobrevin 2 and membraneanchored Syt1 to reconstituted GUVs containing the t-SNARE Syntaxin1/SNAP-25 (Fig. 3A; Malsam et al., 2012). Syt1-R398/399Q was reconstituted into SUVs with similar efficiency as Syt1-wt (Fig. $3 B$ ) and SUVs containing Syt1-RQ docked equally well to GUVs as wild type Syt1 (Fig. $3 C$ ) in the presence of $2 \% \mathrm{PI}(4,5) \mathrm{P}_{2}$. For docking efficiency, the presence or absence of Complexin II was irrelevant. In the absence of $\mathrm{PI}(4,5) \mathrm{P}_{2}$, a large functional difference between Syt1-wt and Syt1-RQ was observed. Whereas Syt1-wt showed a minor impairment in docking efficiency as observed before for synthetic vesicle-vesicle tethering (Vennekate et al., 2012, Parisotto et al., 2012), Syt1-RQ was completely defective in docking SUVs to GUVs lacking $\mathrm{PI}(4,5) \mathrm{P}_{2}$ (Fig. 3C). In addition to the Syt1-R398/ 399Q mutation, a previous study used a similar mutation, but converted the arginines to alanines (Syt1-R398/399A; Gaffaney et al., 2008). We tested this mutation and found indistinguishable effects on SUV-docking to GUVs with the A or Q mutant (Fig. 3B,C). Hence, in this reduced system an intact Syt1-C2B bottom region is critical to mediate Syt1-dependent liposome docking in the absence of $\mathrm{PI}(4,5) \mathrm{P}_{2}$.

\section{Syt1-C2B bottom region is crucial for secretion}

Syt1 null cells lack the $\mathrm{Ca}^{2+}$-dependent fast burst phase of release in chromaffin cells (Voets et al., 2001), which can be reestablished by overexpression of Syt1-wt (Nagy et al., 2006). We tested whether the Syt1-RQ mutant has the same capacity. We analyzed vesicle release using membrane capacitance measurements upon flash photolysis of caged calcium. As anticipated, in Syt1overexpressing (i.e., rescued) syt 1 null cells, the burst phase (i.e., release within the first second) was reestablished compared to syt1 null cells (Fig. 4A-J). In contrast, the Syt1-RQ mutant showed a strong reduction of burst release as compared to Syt1-wt (syt1 null, mean $\Delta C_{\mathrm{m}}=87 \pm 17 \mathrm{fF}, n=28$; syt1 null + Syt1-wt, mean $\Delta C_{\mathrm{m}}=147 \pm 19 \mathrm{fF}, n=23$; syt1 null + Syt1-RQ, mean $\Delta C_{\mathrm{m}}=58 \pm 10 \mathrm{fF} ; n=23$; mean \pm SEM; Kruskal-Wallis test, $p<0.001$; Fig. $4 A, C)$. We observed a similar pattern for the total release (syt1 null, mean $\Delta C_{\mathrm{m}}=165 \pm 28 \mathrm{fF}$; syt1 null + Syt1-wt, mean $\Delta C_{\mathrm{m}}=249 \pm 26 \mathrm{fF} ;$ syt1 null + Syt1-RQ, mean $\Delta C_{\mathrm{m}}=119 \pm 13 \mathrm{fF}$; mean $\pm \mathrm{SEM}$; Kruskal-Wallis test, $p<0.01$; Fig. $4 A, D)$. For the sustained release, a strong tendency to a difference between groups was noted (not significantly different; syt1 null, mean $\Delta C_{\mathrm{m}}=78 \pm 12 \mathrm{fF} ;$ syt1 null + Syt1-wt, mean $\Delta C_{\mathrm{m}}=99 \pm 13$ fF; syt1 null + Syt1-RQ, mean $\Delta C_{\mathrm{m}}=58 \pm 7 \mathrm{fF}$; mean $\pm \mathrm{SEM}$; Kruskal-Wallis test, $p=0.051$; Fig. $4 A, E$ ). Indeed, in a pairwise test, the sustained release in Syt1-RQ-expressing cells was significantly smaller than in WT-rescued cells (Mann-Whitney $U$ test, $p=$ 0.007), confirming lack of rescue also for this parameter.

The kinetic properties of release were analyzed by fitting capacitance changes with a sum of exponentials. We found that fast burst phase secretion was significantly increased in Syt1-wtoverexpressing syt1 null cells compared to control syt1 null or Syt1RQ-overexpressing syt1 null cells (syt1 null, mean $A_{\text {fast }}=16 \pm 4 \mathrm{fF}$; syt1 null + Syt1-wt, mean $A_{\text {fast }}=67 \pm 12 \mathrm{fF}$; syt1 null + Syt1-RQ, $A_{\text {fast }}=14 \pm 4 \mathrm{fF}$; mean \pm SEM; Kruskal-Wallis test, $p<0.001$; Fig. $4 I)$. Furthermore, the Syt1-RQ mutant showed a reduced slow burst phase compared to the other groups, but this was not significant (syt1 null, mean $A_{\text {slow }}=85 \pm 21 \mathrm{fF} ;$ syt 1 null + Syt1-wt, mean $A_{\text {slow }}$ $=48 \pm 11 \mathrm{fF} ;$ syt 1 null + Syt1-RQ, mean $A_{\text {slow }}=34 \pm 7 \mathrm{fF}$; mean \pm 
SEM; Kruskal-Wallis test, $p=0.116$; Fig. $4 J)$. The time constants of the fast and slow release components were unaffected in all the tested conditions (syt1 null, $\tau_{\text {fast }}=$ $22.3 \pm 3.7 \mathrm{~ms}, \tau_{\text {slow }}=0.375 \pm 0.080 \mathrm{~s} ; \mathrm{syt} 1$ null + Syt1-wt, $\tau_{\text {fast }}=18.8 \pm 2.7 \mathrm{~ms}, \tau_{\text {slow }}=$ $0.203 \pm 0.048 \mathrm{~s} ;$ syt1 null + Syt1-RQ, $\tau_{\text {fast }}=24.3 \pm 4.8 \mathrm{~ms}, \tau_{\text {slow }}=0.282 \pm 0.056$ $\mathrm{s}$; mean \pm SEM; Fig. $4 F, G$ ). The fast burst of release is assumed to originate from the readily releasable pool (RRP) of vesicles (Voets, 2000), whereas the slow burst is due to an upstream pool, which is probably not available for immediate release (Walter et al., 2013). Our data indicate that the Syt1C2B bottom arginines, although being dispensable for docking, are crucial for the role of Syt1 in enabling fast burst secretion. These data suggest that the generation or release of the RRP is impaired by the Syt1-RQ mutation in a post-docking step.

\section{Syt1-RQ and Syt1-RA support $\mathrm{Ca}^{2+}$} independent, but abolish $\mathrm{Ca}^{2+}$. dependent, fusion in a cell-free assay To analyze whether the essential role of the Syt1 bottom arginine residues in synchronous release can be reproduced in the cellfree system, we tested the Syt1-RQ and Syt1-RA mutants in $\mathrm{Ca}^{2+}$-synchronized lipid mixing in an in vitro liposome fusion assay. We found that SUVs containing Synaptobrevin2 and Syt1-RQ or Syt1-RA fused readily with GUVs in a $\mathrm{Ca}^{2+}$-independent manner, albeit with $\sim 30 \%$ lower efficiency (Fig. 5), in line with previous observations for the single mutations (R398A or R399A; Gaffaney et al., 2008). Since it was shown previously that fusion in this $\mathrm{v} / \mathrm{t}$-SNARE SUV/GUV assay depends on the presence of Syt1, a minus Syt1 control was omitted (Malsam et al., 2012; Parisotto et al., 2012). Addition of $6 \mu \mathrm{M}$ Complexin II effectively suppressed (clamped) fusion for SUV s containing wild-type Syt1, but less so in SUVs containing Syt1-RQ and Syt1-RA. Moreover, consistent with our observations in intact cells (Fig. 4) and again in line with previous observations for the single mutations (R398A or R399A; Gaffaney et al., 2008), SUVs containing Syt1-RQ and Syt1RA, in contrast to SUVs containing Syt 1-wt, showed little increase in lipid mixing upon addition of $100 \mu \mathrm{M} \mathrm{Ca}{ }^{2+}$ (Fig. 5). Hence, although the Syt1-RQ and Syt1-RA mutations support to a significant degree $\mathrm{Ca}^{2+}$ independent fusion, the Syt1 bottom arginine residues are critical for the $\mathrm{Ca}^{2+}$-dependent reaction.

\section{No dominant effects of Syt1-RQ when overexpressed in wild type chromaffin cells}

It was reported previously that the overexpression of the Syt2-RQ $(\mathrm{R} 399,400 \mathrm{Q})$ mutation in the calyx of Held produces dominant-

A

B

C
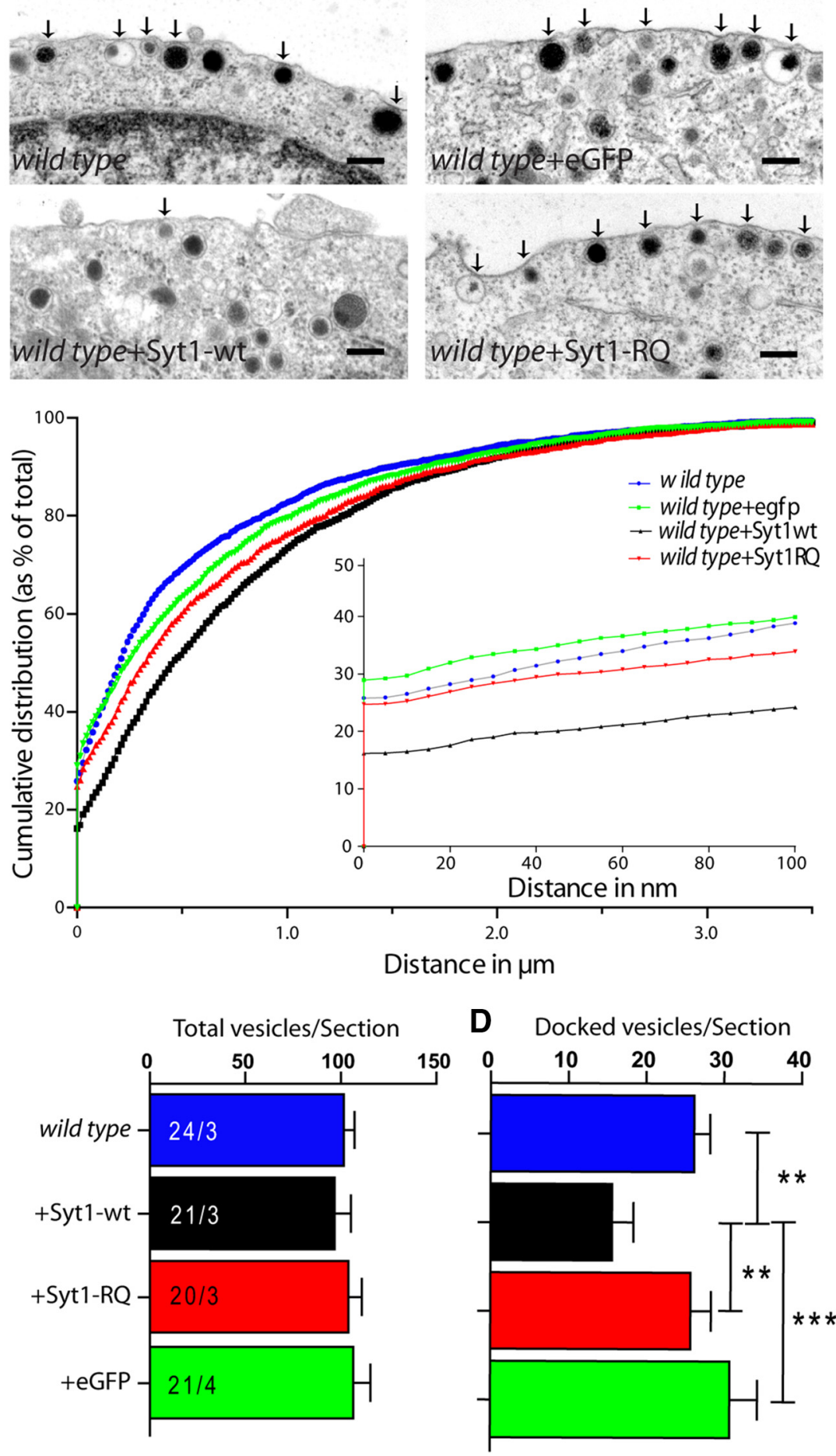

Figure 6. Syt1-wt overexpression in wild type chromaffin cells reduces docking. $\boldsymbol{A}$, Ultrastructural images of different noninfected and infected conditions on the wild-type cell background. Scale bars: $200 \mathrm{~nm}$. Arrows mark docked vesicles. $\boldsymbol{B}$, Normalized cumulative distribution of vesicles as a function of the distance from the plasma membrane. Inset, The distance range of $0-100 \mathrm{~nm}$ from the membrane. $\boldsymbol{C}, \boldsymbol{D}$, Numbers of total $(\boldsymbol{C})$ and docked $(\boldsymbol{D})$ vesicles per section showing a significant reduction in docking in Syt1-wt-overexpressing wild-type cells. Error bars indicate SEM.

negative effects on secretion when expressed on a wild type background (Young and Neher, 2009). We tested whether this was also the case in our system by overexpressing the Syt1-RQ mutant or Syt1-wt on wild type chromaffin cells. Before analyzing its effect on secretion, we investigated the potential effects on the docked pool of vesicles under these conditions. The morphology 
A
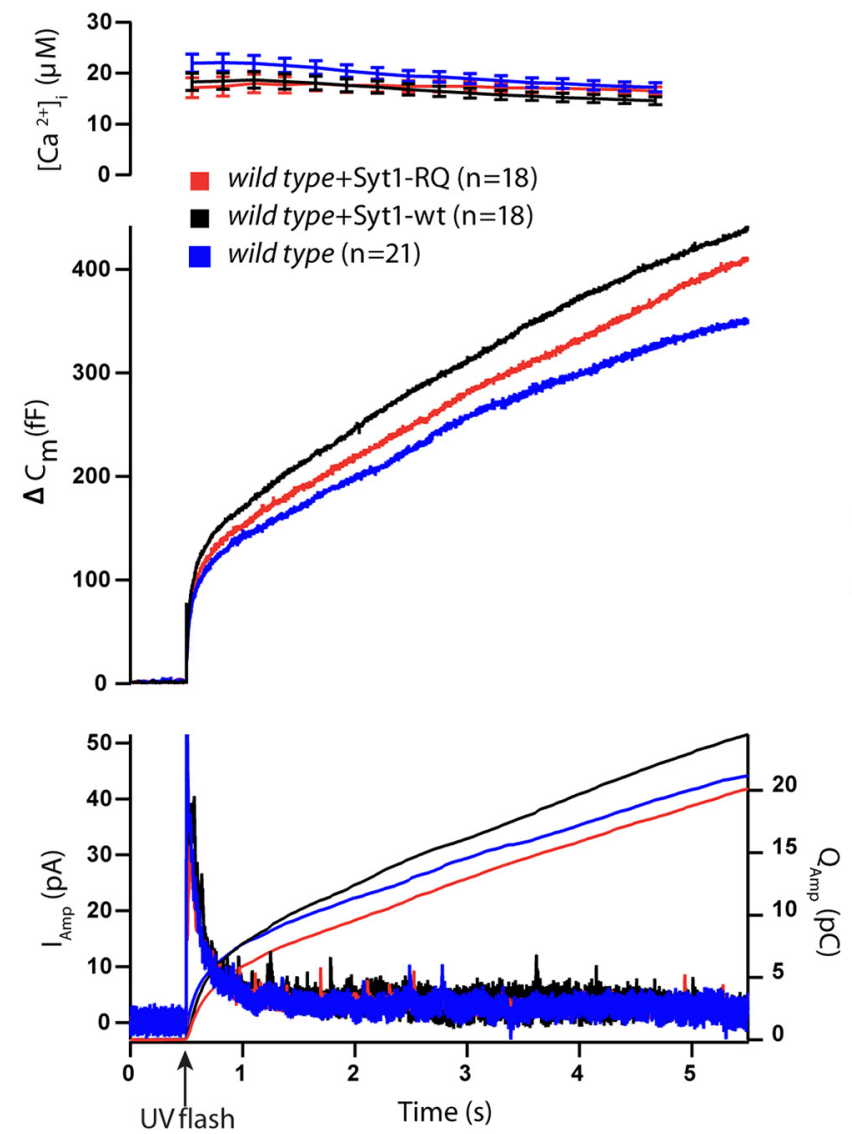

B

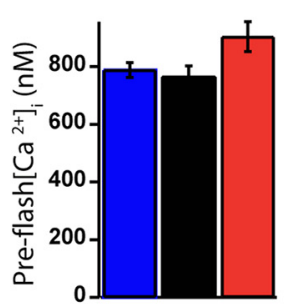

E

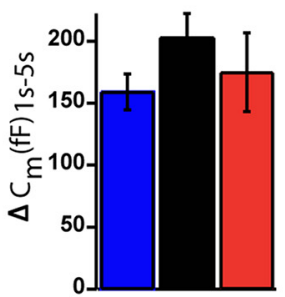

H

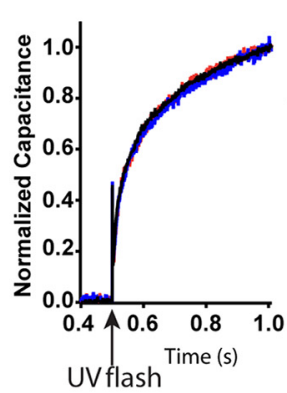

C

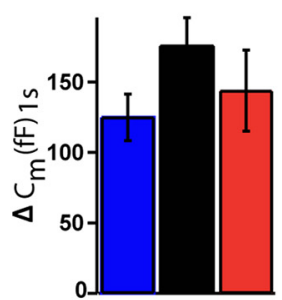

F

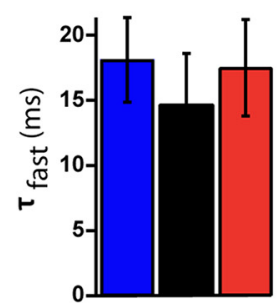

I

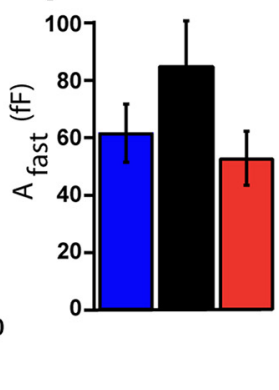

D

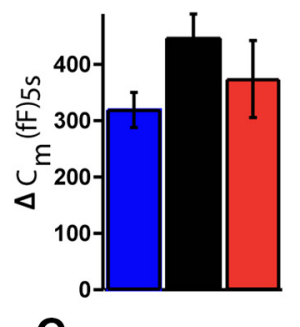

G

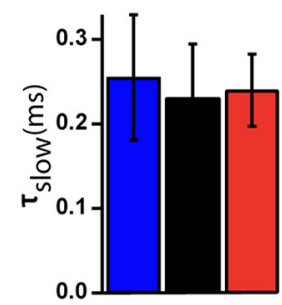

J

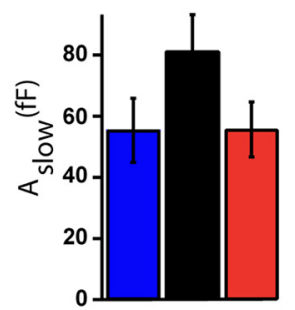

Figure 7. Overexpression of the Syt1-RQ mutant does not alter secretion in wild type chromaffin cells. $A$, Mean membrane capacitance, $\mathrm{Ca}^{2+}$, and amperometry measurements of wild-type (blue), with Syt1-wt overexpression (black) and Syt1-RQ mutant (red). B, Quantification of preflash [Ca ${ }^{2+}$ ]. C, The burst size was slightly higher in Syt1-wt overexpression than in Syt1-RQ overexpression and syt1 null, but this was not significant (Kruskal-Wallis, $p=0.149)$. $\boldsymbol{D}$, The total release $\left(\Delta C_{\mathrm{m}}\right.$ at $5.5 \mathrm{~s}$ ) was unchanged between conditions. $\boldsymbol{E}$, No difference was detected for sustained release $\left(\Delta C_{\mathrm{m}}\right.$ at $\left.5.5-1 \mathrm{~s}\right) . \boldsymbol{F}, \mathbf{G}, \boldsymbol{I}, \boldsymbol{J}$, Fitting individual capacitance traces with a sum of exponentials allowed separating the amplitude and time constant of fast burst secretion from the amplitude and time constant of slow burst secretion. None of the parameters were significantly different between groups. $\boldsymbol{H}$, Scaled version of the mean capacitance traces in $\boldsymbol{A}$ clearly show similar kinetics in the three groups. Overexpression levels of Syt1 constructs were similar (see Fig. 1). Error bars indicate SEM.

of chromaffin cells was similar in all conditions, and the distribution of secretory vesicles was also similar in all conditions except wild type + Syt 1-wt (Fig. 6A,B). Surprisingly, wild type cells overexpressing wild type Syt1, but not cells overexpressing Syt1-RQ, showed a significant decrease in docked vesicles [wild type, $26 \pm$ 2.0 docked vesicles/section; wild type + eGFP, $31 \pm 3.5$ docked vesicles/section; wild type + Syt1-wt $=16 \pm 2.7$ docked vesicles/ section (Student's $t$ test against wild type + eGFP, $p \leq 0.001$, against wild type and wild type + Syt $1-\mathrm{RQ}, p \leq 0.01$ ); wild type + Syt1-RQ, $26 \pm 2.6$ docked vesicles/section; mean \pm SEM; oneway ANOVA, $p=0.002$; Fig. $6 A-D$ ]. This unexpected reduction of docking in cells overexpressing wild type Syt 1 but not Syt1-RQ may relate to the observation in our cell-free system (Fig. 3) that the docking mechanisms differ between wild type Syt 1 and Syt1RA: Whereas Syt 1-RA critically depends on $\mathrm{PI}(4,5) \mathrm{P}_{2}$, Syt 1 wild type can also dock vesicles in the absence of $\mathrm{PI}(4,5) \mathrm{P}_{2}$, probably via interaction with t-SNAREs. Hence, overexpression of Syt1-wt may compete with these $\mathrm{PI}(4,5) \mathrm{P}_{2}$-independent interactions in wild-type cells, whereas overexpression of Syt1-RQ cannot. In any case, no evidence was observed for a dominant-negative effect of the Syt1-RQ mutant on the total vesicle pool or vesicle docking.

Vesicle secretion evoked by calcium uncaging was unaffected by overexpression of Syt1-wt or Syt1-RQ in wild type chromaffin cells (total release, wild type, mean $\Delta C_{\mathrm{m}}=319 \pm$ $31 \mathrm{fF}, n=20$; wild type + Syt 1 -wt, mean $\Delta C_{\mathrm{m}}=447 \pm 43 \mathrm{fF}$, $n=17$; wild type + Syt $1-\mathrm{RQ}$, mean $\Delta C_{\mathrm{m}}=374 \pm 68 \mathrm{fF}, n=$ 20; mean \pm SEM; Kruskal-Wallis, n.s.; Fig. 7A-J), although a nonsignificant increase in burst secretion upon Syt1-wt overexpression (within $1 \mathrm{~s}$ of the flash) was observed (burst release, wild type, mean $\Delta C_{\mathrm{m}}=125 \pm 17 \mathrm{fF}, n=20$; wild type + Syt1-wt, mean $\Delta C_{\mathrm{m}}=176 \pm 20 \mathrm{fF}, n=17$; wild type + Syt1-RQ, mean $\Delta C_{\mathrm{m}}=144 \pm 29 \mathrm{fF}, n=20$; mean \pm SEM; Kruskal-Wallis, $p=0.149$; Fig. $7 C$ ). Consistently, both fast and slow bursts were unchanged between the three groups (fast burst, wild type, $A_{\text {fast }}=62 \pm 10 \mathrm{fF}$; wild type + Syt 1-wt, $A_{\text {fast }}=85 \pm 16 \mathrm{fF}$; wild type + Syt1-RQ, $A_{\text {fast }}=53 \pm 9 \mathrm{fF}$; mean \pm SEM, Kruskal-Wallis, n.s., Fig. 7I; slow burst, wild type, mean $A_{\text {slow }}=55 \pm 11 \mathrm{fF}$; wild type + Syt1-wt, mean $A_{\text {slow }}=81 \pm 12 \mathrm{fF}$; wild type + Syt1-RQ, mean $A_{\text {slow }}=56 \pm$ 9 fF; Kruskal-Wallis, n.s.; Fig. 7J). No differences in time constants for any conditions were observed (wild type, mean $\tau_{\text {fast }}=18 \pm 3 \mathrm{~ms}$, mean $\tau_{\text {slow }}=0.46 \pm 0.20 \mathrm{~s}$; wild type + Syt 1 -wt, mean $\tau_{\text {fast }}=15 \pm 4 \mathrm{~ms}$, mean $\tau_{\text {slow }}=0.23 \pm 0.06 \mathrm{~s}$; wild type + Syt $1-\mathrm{RQ}$, mean $\tau_{\text {fast }}=18 \pm 4 \mathrm{~ms}$, mean $\tau_{\text {slow }}=$ $0.24 \pm 0.04 \mathrm{~ms}$; Kruskal-Wallis, n.s. for both parameters; Fig. $7 F, G)$. 
A subpopulation of the RRP, called the immediately releasable pool (IRP), comprises vesicles in close vicinity of voltagesensitive calcium channels (Alvarez and Marengo, 2011) that fuse first upon depolarization-induced $\mathrm{Ca}^{2+}$ influx. A similar pool was shown to be affected by overexpression of Syt2-RQ in the calyx of Held synapse (Young and Neher, 2009); hence, we investigated the effects of Syt1-RQ overexpression on the IRP in chromaffin cells. The IRP can be distinguished from the RRP by trains of depolarizations of different duration, either 10 $\mathrm{ms}$ (for the IRP) or $100 \mathrm{~ms}$ (RRP) (Voets et al., 1999). We found no significant differences in vesicle secretion upon depolarization in wild-type cells expressing Syt1-WT or Syt1-RQ (IRP, i.e., capacitance change elicited by five consecutive $10 \mathrm{~ms}$ depolarizations; wild type, $\Delta C_{\mathrm{m}}=$ $29 \pm 5 \mathrm{fF}, n=14$; wild type + Syt1-wt, $\Delta C_{\mathrm{m}}=31 \pm 4 \mathrm{fF}, n=28$; wild type + Syt1-RQ, $\Delta C_{\mathrm{m}}=25 \pm 4 \mathrm{fF}, n=26$; Kruskal-Wallis n.s.; Fig. $8 A, B)$. Moreover, the RRP (detected as the capacitance increase until the end of the fourth $100 \mathrm{~ms}$ depolarization) and total membrane capacitance after a UV flash had photoreleased $\mathrm{Ca}^{2+}$ to release any remaining vesicles (end of trace) were not significantly different in any condition (Fig. $8 C, D)$. These data indicate that Syt1-RQ overexpression does not result in a dominant-negative phenotype on vesicle fusion, and that the IRP remains unaffected under these conditions. Thus, overall, the Syt1-RQ mutant does not participate in $\mathrm{Ca}^{2+}$-triggered secretion in chromaffin cells and also does not interfere with it.

\section{Discussion}

In the current study, we investigated the role of the Syt1-C2B domain bottom residues in secretory granule docking and secretion, using the Syt1 R398Q/399Q mutant. This mutant severely disrupted synaptic transmission in hippocampal neurons (Xue et al., 2008), and, using a similar mutation in Syt2 (R399Q/400Q, homologous positions to R398, R399 in Syt1), it was concluded that $\mathrm{C} 2 \mathrm{~B}$ domain bottom residues affect positional priming in the calyx of Held (Young and Neher, 2009). Applying ultrastructural analysis, patch-clamp, and cell-free assays, we found that this mutation fully restored docking, but made docking in vitro strictly $\mathrm{PI}(4,5) \mathrm{P}_{2}$ dependent and failed to restore secretion of fast burst release in syt1 null chromaffin cells and in a cell-free fusion assay. These impairments of secretion were not the result of a dominant-negative effect of the Syt1-RQ mutant, as docking and secretion in wild-type cells overexpressing this mutant remained unaffected.

The role of Syt 1 in vesicle docking

The Syt1-RQ mutant restored docking in syt1 null cells (Fig. 2) and supported docking in a cell-free assay (Fig. 3), but did not restore secretion in syt1 null cells (Fig. 4), and the Syt1-RQ and Syt1-RA mutants did not support $\mathrm{Ca}^{2+}$-dependent lipid mixing in a cell-free assay. This indicates that the molecular properties of Syt1 relevant for vesicle docking and for fusion are different. Mutation of the C2B bottom surface of Syt1 does not affect the extent of docking, but does eliminate $\mathrm{Ca}^{2+}$-dependent membrane fusion. An important indication for the underlying differences between docking and fusion came from the cell-free docking assay. This assay revealed that mutations in the $\mathrm{C} 2 \mathrm{~B}$ bottom surface make docking critically dependent on $\mathrm{PI}(4,5) \mathrm{P}_{2}$. This observation suggests that wild-type Syt1 can use $\mathrm{PI}(4,5) \mathrm{P}_{2}$-dependent and $\mathrm{PI}(4,5) \mathrm{P}_{2}$ independent principles to dock vesicles, and the mutations disrupt the $\mathrm{PI}(4,5) \mathrm{P}_{2}$-independent principle. Hence, the $\mathrm{C} 2 \mathrm{~B}$ bottom surface appears to be involved in a $\mathrm{PI}(4,5) \mathrm{P}_{2}$ independent docking principle. Furthermore, since Syt1-RQ rescues docking in syt1 null cells, docking in living chromaffin cells is probably $\mathrm{PI}(4,5) \mathrm{P}_{2}$-dependent.

Given the fact that this $\mathrm{PI}(4,5) \mathrm{P}_{2}$-independent docking principle was observed in a highly reduced cell-free system, the number of possible mechanisms is limited: interactions with the t-SNAREs and/or with other phospholipids. Under resting conditions (low $\mathrm{Ca}^{2+}$ ), Syt1 is reported to bind to (monomeric) SNAP-25 and Syntaxin1A and to the binary and the ternary SNARE complex (Rizo et al., 2006; Chapman, 2008; Jahn and Fasshauer, 2012; Kim et al., 2012; Südhof, 2012). The polybasic region on the side of Syt1-C2B domain, around K325, K326, $\mathrm{K} 327$, and $\mathrm{K} 331$, is a prominent interaction surface (Rickman et al., 2004; Martens et al., 2007; Lai et al., 2011; Wang et al., 2011; Zhou et al., 2013). Additional contact sites have been proposed, 
including the $\mathrm{C} 2 \mathrm{~A}$ domain and the bottom surface of the $\mathrm{C} 2 \mathrm{~B}$ domain, where R398 and R399 are located (Lai et al., 2011; Zhou et al., 2013). A previous study concluded that this bottom surface is close to the SNARE interface, but still sufficiently exposed to allow other interactions (Choi et al., 2010). Mutations of negative charges in the middle region of SNAP-25, which interact with the Syt1 polybasic region, are sufficient to produce a docking defect in chromaffin cells (Mohrmann et al., 2013), while Syt1-RQexpressing cells show no docking defect (Fig. 2). Hence, docking tolerates mutations in the $\mathrm{C} 2 \mathrm{~B}$ domain bottom region, but not the disruption of Syt1-tSNARE interaction. This suggests that the Syt1-tSNARE interaction is probably preserved in Syt1-RQ and Syt1-RA, and the interaction with other phospholipids (Martens et al., 2007; Gaffaney et al., 2008; Kuo et al., 2009; Wang et al., 2011; Park et al., 2012; Vennekate et al., 2012) might be disrupted and exposed upon removal of PI $(4,5) \mathrm{P}_{2}$ in the SUV/GUV docking assay. Indeed, R398A impaired Syt1 binding to SNARE liposomes without PI(4,5) $\mathrm{P}_{2}$ (Gaffaney et al., 2008), and two studies that measured $\mathrm{Ca}^{2+}$-dependent liposome aggregation observed that R398/399Q abolished liposome aggregation (Araç et al., 2006; Xue et al., 2008). In our GUV/SUV assay, docking was preserved with the R398/399Q and RA mutations as long as $\mathrm{PI}(4,5) \mathrm{P}_{2}$ was present (Fig. 3). Finally, separate interactions with the tSNAREs might also account for the role of the C2B bottom surface in $\operatorname{PI}(4,5) \mathrm{P}_{2}$-dependent docking. Probably the most likely scenario is that docking is effectuated via multiple interactions, which are not necessarily of high affinity, but due to their avidity and a potential involvement of multiple Syt1 molecules on the vesicle (cooperativity), can effectively dock vesicles to the target membrane. It remains to be determined to what extent the strict $\mathrm{PI}(4,5) \mathrm{P}_{2}$ dependence of docking by Syt1-RQ- and Syt1-RAcontaining vesicles recapitulates the situation in living cells (something that cannot be easily tested), but in any case, our data show that in intact chromaffin cells, docking is probably driven by redundant electrostatic interactions in any of a number of different alternative configurations.

\section{The role of Syt 1 in vesicle priming and fusion}

In line with previous results, wild-type cells and syt1 null cells expressing Syt1 showed similar secretion levels (Nagy et al., 2006). Syt1-RQ failed to restore the RRP and even tended to reduce remaining release further (although not significantly; Fig. 4), and Syt1-RQ and Syt1-RA mutants did not show $\mathrm{Ca}^{2+}$ induced SUV-GUV lipid mixing (Fig. 5). Hence, our data confirm the importance of the C2B domain bottom residues of Syt1 for calcium-triggered synchronous release, as observed before in neurons (Xue et al., 2008). Similar to this study, none of our experiments in chromaffin cells expressing the Syt1-RQ mutant produced evidence that this mutant retains any fusion activity. However, the SUV-GUV lipid mixing assay revealed that Syt1-RQ and Syt1-RA show substantial $\mathrm{Ca}^{2+}$-independent lipid mixing (but not $\mathrm{Ca}^{2+}$ dependent), consistent with their unaltered vesicle docking properties in the presence of $\mathrm{PI}(4,5) \mathrm{P}_{2}$. Although $\mathrm{Ca}^{2+}$-independent lipid mixing is a well known property of Syt1 in cell-free systems (Gaffaney et al., 2008; Malsam et al., 2012), is not known to what extent this activity relates to aspects of Syt1 function in living cells, for instance, to spontaneous synaptic vesicle fusion in synapses [not reported by Xue et al. (2008)]. Chromaffin cells hardly show spontaneous events. In fact, we detected not a single amperometric spike during $180 \mathrm{~s}$ recordings of six chromaffin cells expressing either Syt1-wt and Syt1-RQ (data not shown). Together with the overwhelming evidence for the involvement of the $\mathrm{Ca}^{2+}$-binding loops at the "top" of the C2B domain in fusion (Rizo et al., 2006; Chapman, 2008; Jahn and Fasshauer, 2012; Kim et al., 2012; Südhof, 2012), the clear role for the arginines in the bottom domain suggests that these two opposite sides of the $\mathrm{C} 2 \mathrm{~B}$ domain participate in the final $\mathrm{Ca}^{2+}$-dependent triggering of fusion, as proposed previously (Araç et al., 2006; Xue et al., 2008).

Expression of Syt2 R399Q/400Q in wild type calyx of Held resulted in dominant-negative effects on neurotransmitter release when stimulated by depolarization, but not upon $\mathrm{Ca}^{2+}$ uncaging (Young and Neher, 2009). It was concluded that Syt2 RQ is defective in positional priming, such that vesicles are mislocalized with respect to $\mathrm{Ca}^{2+}$ channels. Isolated chromaffin cells have no active zones as neuronal synapses do, and positional priming is not a major phenomenon. However, a small vesicle pool (IRP) has been identified that can be triggered to fuse with short (10 ms) depolarizations, expected to produce discrete, local increases in intracellular $\mathrm{Ca}^{2+}$ (Voets et al., 1999). These vesicles are colocalized with $\mathrm{Ca}^{2+}$ channels, but it is not clear whether they are molecularly different from other RRP vesicles. IRP vesicles might be drawn from a homogeneous RRP during short depolarizations by chance. In any case, the IRP is not reduced upon expression of the Syt1-RQ mutant in wild-type cells, and $\mathrm{Ca}^{2+}$ uncaging $\mathrm{did}$ not result in enhanced secretion of potentially mislocalized vesicles when expressing the Syt1-RQ mutation in syt1 null or wildtype cells. Hence, we conclude that the Syt1-RQ mutation does not affect positional priming in chromaffin cells. Instead, our data support the idea that the Syt1 bottom domain physically and locally couples SNARE or lipid interactions to the $\mathrm{Ca}^{2+}$ dependent reactions mediated by the top domain (Araç et al., 2006; Xue et al., 2008). We conclude that Syt1-C2B bottom domain is dispensable for docking due to the existence of multiple alternative docking mechanisms, but plays a crucial role in vesicle secretion, indicating that the $\mathrm{C} 2 \mathrm{~B}$ domain bottom residues are required specifically for a post-docking step to achieve calcium-dependent vesicle secretion.

\section{References}

Aarts E, Verhage M, Veenvliet JV, Dolan CV, van der Sluis S (2014) A solution to dependency: using multilevel analysis to accommodate nested data. Nat Neurosci 17:491-496. CrossRef Medline

Alvarez YD, Marengo FD (2011) The immediately releasable vesicle pool: highly coupled secretion in chromaffin and other neuroendocrine cells. J Neurochem 116:155-163. CrossRef Medline

Araç D, Chen X, Khant HA, Ubach J, Ludtke SJ, Kikkawa M, Johnson AE, Chiu W, Südhof TC, Rizo J (2006) Close membrane-membrane proximity induced by $\mathrm{Ca}(2+)$-dependent multivalent binding of synaptotagmin-1 to phospholipids. Nat Struct Mol Biol 13:209-217. CrossRef Medline

Bruns, D (2004) Detection of transmitter release with carbon fiber electrodes. Methods 33:312-321. CrossRef Medline

Chapman ER (2008) How does synaptotagmin trigger neurotransmitter release? Annu Rev Biochem 77:615-641. CrossRef Medline

Choi UB, Strop P, Vrljic M, Chu S, Brunger AT, Weninger KR (2010) Single-molecule FRET-derived model of the synaptotagmin 1-SNARE fusion complex. Nat Struct Mol Biol 17:318-384. CrossRef Medline

de Wit H, Walter AM, Milosevic I, Gulyás-Kovács A, Riedel D, Sørensen JB, Verhage M (2009) Synaptotagmin-1 docks secretory vesicles to syntaxin-1/SNAP-25 acceptor complexes. Cell 138:935-946. CrossRef Medline

Ehrengruber MU, Lundstrom K (2007) Alphaviruses: Semliki Forest virus and Sindbis virus vectors for gene transfer into neurons. Curr Protoc Neurosci. 4:4.22. Medline

Fernández-Chacón R, Königstorfer A, Gerber SH, García J, Matos MF, Stevens CF, Brose N, Rizo J, Rosenmund C, Südhof TC (2001) Synaptotagmin I functions as a calcium regulator of release probability. Nature 410: 41-49. CrossRef Medline

Fernandez I, Araç D, Ubach J, Gerber SH, Shin O, Gao Y, Anderson RG, Südhof TC, Rizo J (2001) Three-dimensional structure of the synap- 
totagmin 1 C2B-domain: synaptotagmin 1 as a phospholipid binding machine. Neuron 32:1057-1069. CrossRef Medline

Gaffaney JD, Dunning FM, Wang Z, Hui E, Chapman ER (2008) Synaptotagmin $\mathrm{C} 2 \mathrm{~B}$ domain regulates $\mathrm{Ca} 2+$-triggered fusion in vitro: critical residues revealed by scanning alanine mutagenesis. J Biol Chem 283: 31763-31775. CrossRef Medline

Geppert M, Goda Y, Hammer RE, Li C, Rosahl TW, Stevens CF, Südhof TC (1994) Synaptotagmin I: a major Ca2+ sensor for transmitter release at a central synapse. Cell 79:717-727. CrossRef Medline

Honigmann A, van den Bogaart G, Iraheta E, Risselada HJ, Milovanovic D, Mueller V, Müllar S, Diederichsen U, Fasshauer D, Grubmüller H, Hell SW, Eggeling C, Kühnel K, Jahn R (2013) Phosphatidylinositol 4,5bisphosphate clusters act as molecular beacons for vesicle recruitment. Nat Struct Mol Biol 20:679-686. CrossRef Medline

Imig C, Min SW, Krinner S, Arancillo M, Rosenmund C, Südhof TC, Rhee J, Brose N, Cooper BH (2014) The morphological and molecular nature of synaptic vesicle priming at presynaptic active zones. Neuron 84:416431. CrossRef Medline

Jahn R, Scheller RH (2006) SNAREs-engines for membrane fusion. Nat Rev Mol Cell Biol 7:631-643. CrossRef Medline

Jahn R, Fasshauer D (2012) Molecular machines governing exocytosis of synaptic vesicles. Nature 490:201-207. CrossRef Medline

Jorgensen EM, Hartwieg E, Schuske K, Nonet ML, Jin Y, Horvitz HR (1995) Defective recycling of synaptic vesicles in synaptotagmin mutants of Caenorhabditis elegans. Nature 378:196-199. CrossRef Medline

Kim JY, Choi BK, Choi MG, Kim SA, Lai Y, Shin YK, Lee NK (2012) Solution single-vesicle assay reveals PIP2-mediated sequential actions of synaptotagmin-1 on SNAREs. EMBO J 31:2144-2155. CrossRef Medline

Kuo W, Herrick DZ, Ellena JF, Cafiso DS (2009) The calcium-dependent and calcium-independent membrane binding of synaptotagmin 1: two modes of C2B binding. J Mol Biol 387:284-294. CrossRef Medline

Lai AL, Huang H, Herrick DZ, Epp N, Cafiso DS (2011) Synaptotagmin 1 and SNAREs form a complex that is structurally heterogeneous. J Mol Biol 405:696-706. CrossRef Medline

Lindau M, Neher E (1988) Patch-clamp techniques for time-resolved capacitance measurements in single cells. Pflugers Arch 411:137-146. Medline

Loewen CA, Lee SM, Shin YK, Reist NE (2006) C2B polylysine motif of synaptotagmin facilitates a $\mathrm{Ca}^{2+}$-independent stage of synaptic vesicle priming in vivo. Mol Biol Cell 17:5211-5226. CrossRef Medline

Mahal LK, Sequeira SM, Gureasko JM, Söllner TH (2002) Calciumindependent stimulation of membrane fusion and SNAREpin formation by synaptotagmin I. J Cell Biol 158:273-282. CrossRef Medline

Malsam J, Parisotto D, Bharat TA, Scheutzow A, Krause JM, Briggs JA, Söllner TH (2012) Complexin arrests a pool of docked vesicles for fast Ca2+dependent release. EMBO J 31:3270-3281. CrossRef Medline

Martens S, Kozlov MM, McMahon HT (2007) How synaptotagmin promotes membrane fusion. Science 316:1205-1208. CrossRef Medline

Mohrmann R, de Wit H, Connell E, Pinheiro PS, Leese C, Bruns D, Davletov B, Verhage M,Sørensen JB (2013) Synaptotagmin interaction with SNAP-25 governs vesicle docking, priming, and fusion triggering. J Neurosci 33:14417-14430. CrossRef Medline

Nagy G, Kim JH, Pang ZP, Matti U, Rettig J, Südhof TC, Sørensen JB (2006) Different effects on fast exocytosis induced by synaptotagmin 1 and 2 isoforms and abundance but not by phosphorylation. J Neurosci 26:632643. CrossRef Medline

Pang Z, Südhof T (2010) Cell biology of Ca2+-triggered exocytosis. Curr Opin Cell Biol 22:496-505. CrossRef Medline

Pang ZP, Sun J, Shin OH, Meyer AC, Rosenmund C, Südhof TC (2006) A gain-of-function mutation in synaptotagmin-1 reveals a critical role of $\mathrm{Ca} 2+$-dependent soluble $\mathrm{N}$-ethylmaleimide- sensitive factor attachment protein receptor complex binding in synaptic exocytosis. J Neurosci 26: 12556-12565. Medline

Parisotto D, Malsam J, Scheutzow A, Krause JM, Söllner TH (2012)
SNAREpin assembly by Munc18-1 requires previous vesicle docking by synaptotagmin 1. J Biol Chem 287:31041-31049. CrossRef Medline

Park Y, Hernandez JM, van den Bogaart G, Ahmed S, Holt M, Riedel D, Jahn R (2012) Controlling synaptotagmin activity by electrostatic screening. Nat Struct Mol Biol 19:991-997. CrossRef Medline

Reist NE, Buchanan J, Li J, DiAntonio A, Buxton EM, Schwarz TL (1998) Morphologically docked synaptic vesicles are reduced in synaptotagmin mutants of Drosophila. J Neurosci 18:7662-7673. Medline

Rickman C, Archer DA, Meunier FA, Craxton M, Fukuda M, Burgoyne RD, Davletov B (2004) Synaptotagmin interaction with the syntaxin/ SNAP-25 dimer is mediated by an evolutionarily conserved motif and is sensitive to inositol hexakisphosphate. J Biol Chem 279:12574-12579. CrossRef Medline

Rizo J, Chen X, Araç D (2006) Unraveling the mechanisms of synaptotagmin and SNARE function in neurotransmitter release. Trends Cell Biol 16:339-350. CrossRef Medline

Schindelin J, Arganda-Carreras I, Frise E, Kaynig V, Longair M, Pietzsch T, Preibisch S, Rueden C, Saalfeld S, Schmid B, Tinevez JY, White DJ, Hartenstein V, Eliceiri K, Tomancak P, Cardona A (2012) Fiji: an opensource platform for biological-image analysis. Nat Methods 9:676-682. CrossRef Medline

Schonn JS, Maximov A, Lao Y, Südhof TC, Sørensen JB (2008) Synaptotagmin-1 and -7 are functionally overlapping $\mathrm{Ca} 2+$ sensors for exocytosis in adrenal chromaffin cells. Proc Natl Acad Sci U S A 105:3998-4003. CrossRef Medline

Sørensen JB, Fernández-Chacón R, Südhof TC, Neher E (2003) Examining synaptotagmin 1 function in dense core vesicle exocytosis under direct control of Ca2 +. J Gen Physiol 122:265-276. CrossRef Medline

Südhof TC (2012) Calcium control of neurotransmitter release. Cold Spring Harbor Perspect Biol 4:a011353. CrossRef

Südhof TC, Rothman JE (2009) Membrane fusion: grappling with SNARE and SM proteins. Science 323:474-477. CrossRef Medline

Vennekate W, Schröder S, Lin CC, van den Bogaart G, Grunwald M, Jahn R, Walla PJ (2012) Cis- and trans-membrane interactions of synaptotagmin-1. Proc Natl Acad Sci U S A 109:11037-11042. CrossRef Medline

Verhage M, Sørensen JB (2008) Vesicle docking in regulated exocytosis. Traffic 9:1414-1424. CrossRef Medline

Voets T (2000) Dissection of three Ca2+-dependent steps leading to secretion in chromaffin cells from mouse adrenal slices. Neuron 28:537-545. CrossRef Medline

Voets T, Neher E, Moser T (1999) Mechanisms underlying phasic and sustained secretion in chromaffin cells from mouse adrenal slices. Neuron 23:607-615. CrossRef Medline

Voets T, Moser T, Lund PE, Chow RH, Geppert M, Südhof TC, Neher E (2001) Intracellular calcium dependence of large dense-core vesicle exocytosis in the absence of synaptotagmin I. Proc Natl Acad Sci U S A 98:11680-11685. CrossRef Medline

Walter A, Pinheiro P, Verhage M, Sørensen J (2013) A sequential vesicle pool model with a single release sensor and a Ca2+-dependent priming catalyst effectively explains $\mathrm{Ca} 2+$-dependent properties of neurosecretion. PLoS Comput Biol 9:e1003362. CrossRef Medline

Wang Z, Liu H, Gu Y, Chapman ER (2011) Reconstituted synaptotagmin I mediates vesicle docking, priming, and fusion. J Cell Biol 195:1159-1170. CrossRef Medline

Weber T, Zemelman BV, McNew JA, Westermann B, Gmachl M, Parlati F, Söllner TH, Rothman JE (1998) SNAREpins: minimal machinery for membrane fusion. Cell 92:759-772. CrossRef Medline

Xue M, Ma C, Craig TK, Rosenmund C, Rizo J (2008) The Janus-faced nature of the $\mathrm{C}(2) \mathrm{B}$ domain is fundamental for synaptotagmin-1 function. Nat Struct Mol Biol 15:1160-1168. CrossRef Medline

Young SM Jr, Neher E (2009) Synaptotagmin has an essential function in synaptic vesicle positioning for synchronous release in addition to its role as a calcium sensor. Neuron 63:482-496. CrossRef Medline

Zhou A, Brewer KD, Rizo J (2013) Analysis of SNARE complex/synaptotagmin-1 interactions by one-dimensional NMR spectroscopy. Biochemistry 52:34463456. CrossRef Medline 